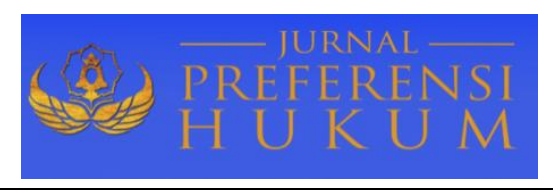

Jurnal Preferensi Hukum | ISSN: XXXX | E-ISSN: XXXX Vol. 1, No. 2 - September 2020, Hal. 191-195| Available Online at https://www.ejournal.warmadewa.ac.id/index.php/juprehum DOI: http://doi.org/10.22225/jph.v1i2.2388.191-195

\title{
SANKSI PIDANA TERHADAP PELAKU PENCULIKAN ANAK
}

\author{
Ardi Putra Dewa Agung, I Made Sepud, A. A. Sagung Laksmi Dewi \\ Fakultas Hukum Universitas Warmadewa, Denpasar-Bali, Indonesia
}

\begin{abstract}
Abstrak
Penculikan anak dilakukan seseorang tanpa hak untuk tujuan memungkinkan orang tersebut berada di bawah kekuasaan para penculik. Seorang penculik menargetkan anak sebagai korban. Berdasarkan situs berita online liputan6.com, Ketua Komnas Perlindungan Anak Arist Merdeka Sirait mengatakan, kasus Penculikan Anak terus meningkat dari tahun 2014 hingga 2017. Isu terkait kasus yang akan diteliti dalam penelitian kali ini adalah: (1) Pengaturan tentang pertanggungjawaban pidana bagi pelaku penculikan anak, (2) Sanksi pidana dan penghukuman bagi pelaku penculikan anak. Dari hasil eksplorasi yang dilakukan dengan metode penelitian normatif dalam penelitian ini ditemukan bahwa pertanggungjawaban pidana pelaku penculikan anak diatur dalam Pasal 76F Undang-Undang Republik Indonesia Nomor 35 Tahun 2014 tentang Perubahan Atas UndangUndang Nomor 23 Tahun 2014. 2002 tentang Perlindungan Anak. Penculikan seorang anak dapat dikenakan pertanggungjawaban pidana jika pelaku telah melakukan perbuatan yang memenuhi unsur kenakalan. Mengenai sanksi pidana dan penghukuman penculik anak yang terbukti secara sah dan meyakinkan di mata hukum melakukan tindak pidana penculikan anak dapat dijatuhi hukuman penjara dan denda. Kriminalisasi penculik anak bergantung pada peran hakim yang memeriksa dan mengadili kasus tersebut. Hakim diberi kebebasan untuk mengatur jenis pidana, tindak pidana, atau pidana tinggi rendahnya.
\end{abstract}

Kata Kunci: Anak Korban; Penculikan Anak; Sanksi Pidana

\begin{abstract}
Kidnapping is an act committed by someone without the right for the purpose of enabling such person under the powers of the kidnappers. An abductor targets child as a victim. Based on the online news website liputan6.com, Chairman of the National Commission for Child Protection Arist Merdeka Sirait said the Child Abduction case continues to increase from 2014 to 2017. The issues regarding the case to be examined in the present study are: (1) The regulation regarding criminal liability of offenders of child abduction, (2) The criminal sanction and condemnation towards the offenders of child abduction. From the results of an exploration conducted with the normative research method in this study it was found that the criminal liability of the offenders of child abduction is regulated in Article 76F Indonesian Law No. 35 of 2014 concerning the Amendment towards the Law No. 23 of 2002 concerning Child Protection. The kidnapping of a child may be held to criminal liability if the offender has committed an act fulfilling the elements of delinquency. Regarding criminal sanctions and condemnation against child abductors who are proven guilty of legally and convincingly in the eyes of the law of committing the crime of kidnapping of a child can be sentenced in the form of imprisonment and a fine penalty. Criminalization of child abductors depends on the role of the judge who examines and prosecutes the case. Judges are given the freedom to set the type of criminal, criminal conduct, or the high and low criminal.
\end{abstract}

Keywords: Child Victim; Child Abduction; Criminal Sanction

\section{PENDAHULUAN}

Penculikan adalah perbuatan membawa pergi seseorang tanpa hak dengan maksud agar orang tersebut berada di bawah kekuasaan penculik (Daipon, 2017). Korban penculikan tidak hanya orang dewasa, tetapi juga anak-anak. Berdasarkan situs berita online liputan6.com, Ketua Komisi Nasional Perlindungan Anak (Komnas PA) Arist Merdeka Sirait mengatakan setiap tahun kasus Penculikan Anak terus meningkat selama 3 tahun belakangan ini mulai dari Tahun 2014 sampai 2017 (Fakta, 2017). Menurut Arist, para pelaku penculikan memiliki tujuan yang berbeda-beda: pertama, ada yang diculik kemudian diadopsi secara ilegal; yang kedua, menculik anak dengan alasan dendam sampai meminta uang tebusan; yang ketiga, yang cukup marak yaitu dipekerjakan secara paksa menjadi anak jalanan dan pengemis. Tak berhenti di situ, korban penculikan seringkali dijadikan pekerja seks 
komersial (Fakta, 2017). Tindak pidana penculikan secara umum diatur dalam Pasal 328-331 Kitab Undang-Undang Hukum Pidana, dan terkait dengan penculikan anak secara khusus (lex specialis) diatur dalam Pasal 76F Undang-Undang Nomor 35 Tahun 2014 tentang Perubahan atas UndangUndang Nomor 23 Tahun 2002 tentang Perlindungan Anak. Pasal 76F Undang-Undang Nomor 35 Tahun 2014 menyebutkan bahwa "Setiap orang dilarang menempatkan, membiarkan, melakukan, menyuruh melakukan, atau turut serta melakukan penculikan, penjualan, dan/atau perdagangan Anak."

Untuk ancaman pidananya diatur dalam Pasal 83 Undang-Undang Nomor 35 Tahun 2014. Pasal tersebut menyebutkan bahwa "Setiap orang yang melanggar ketentuan sebagaimana dimaksud dalam Pasal 76F dipidana dengan pidana penjara paling singkat 3 (tiga) tahun dan paling lama 15 (lima belas) tahun dan denda paling sedikit Rp60.000.000,00 (enam puluh juta rupiah) dan paling banyak Rp300.000.000,00 (tiga ratus juta rupiah)."

Terkait korban sebagai anak tindak pidana kejahatan, khususnya perdagangan dan penculikan kajian telah banyak diluncur. Pengaturan tentang perdagangan orang merupakan rumusan pasal 297 KUHP dimana pasal ini merupakan satu-satunya pasal yang mengatur tentang perdagangan perempuan dan anak laki-laki. Sedangkan ketentuan dalam Undang-Undang Nomor 23 Tahun 2002 tentang Perlindungan Anak, Pasal 68 ayat (2), Pasal 78; pasal 83; pasal 84; pasal 85; dan pasal 88. Pada intinya pasal-pasal dalam KUHP atau UU Perlindungan Anak menghukum pelaku yang terkait dengan masalah perdagangan dengan memberikan sanksi (Hukum \& Ham, 2016). Ada beberapa motif penculikan anak seperti: uang, pemerasan, dendam, masalah politik, eksploitasi seksual, lalu perdagangan anak untuk perdagangan organ (Daipon, 2017). Dalam pandangan hukum Islam, hukuman bagi pelaku tindak pidana pencabutan perempuan yang belum dewasa oleh anak mengisyaratkan bahwa sanksi pidana yang dijatuhkan harus memberikan manfaat agar pelaku yang dipidana menjadi takut untuk melakukan tindak pidana lain (Arsyad, 2017). Perdagangan manusia merupakan kejahatan yang terorganisir dan tersistematis, dimana orang yang termasuk didalamnya memiliki kepentingan pribadi atau kelompok untuk mendapat keuntungan, dan tindakan ini harus dilarang dan diberantas sesuai peraturan hukum (Daud \& Sopoyono, 2019).

Berdasarkan apa yang telah diuraikan dalam latar belakang masalah, kajian ini menyoroti dua isu: 1) Bagaimanakah pengaturan hukum tentang pertanggungjawaban pidana terhadap pelaku penculikan anak? dan 2) Bagaimanakah sanksi pidana dan pemidanaan terhadap pelaku penculikan anak? Tujuan dari penelitian ini ialah 1) untuk mengetahui pengaturan tentang pertanggungjawaban pidana terhadap pelaku penculikan anak; dan 2) untuk mengetahui sanksi pidana dan pemidanaan terhadap pelaku penculikan anak.

\section{METODE PENELITIAN}

Untuk memecahkan suatu permasalahan dalam penelitian diperlukan metode yang digunakan untuk mencari data atau bahan hukum. Tipe penelitian yang digunakan dalam kajian ini adalah jenis penelitian normatif. Penelitian hukum normatif adalah penelitian hukum yang mengkaji hukum tertulis dari berbagai aspek, yaitu aspek teori, sejarah, filosofi, perbandingan, struktur dan komposisi, lingkup dan materi, konsistensi, penjelasan umum dan pasal demi pasal, formalitas dan kekuatan mengikat suatu undang-undang, serta bahasa hukum yang digunakan (Johan, 2008: 13).

Pendekatan masalah yang digunakan adalah pendekatan perundang-undangan dan pendekatan konseptual. Bahan hukum yang dipergunakan dalam penelitian ini terdiri dari 2 (dua) macam, yaitu: 1) bahan hukum primer, yang bersumber dari peraturan perundang-undangan yang berkaitan dengan pokok permasalahan yang dibahas dan 2) bahan hukum sekunder, yang diperoleh dari buku-buku, kamus-kamus hukum, hasil-hasil penelitian para ahli hukum, jurnal-jurnal hukum mengenai hukum pidana tentang penculikan anak, dan website-website yang menelaah tentang tindak pidana penculikan anak.

Pengumpulan bahan hukum dilakukan dengan cara melakukan studi pencatatan, yaitu dengan membaca peraturan perundang-undangan dan buku-buku literatur yang berkaitan dengan isu penculikan anak dan dikutip sesuai dengan relevansinya untuk keperluan analisa. Bahan-bahan hukum yang telah terkumpul tersebut diolah dan dianalisis dengan menggunakan penafsiran hukum yang kemudian disajikan dalam bentuk deskriptif analisis untuk memberikan gambaran dengan cara menguraikan dalam bentuk skripsi. 


\section{HASIL DAN PEMBAHASAN}

\section{Pengaturan Hukum tentang Pertanggungjawaban Pidana terhadap Pelaku Penculikan Anak}

Terdapat berbagai macam tindak pidana, salah satu tindak pidana tersebut adalah tindak pidana penculikan. Penculikan merupakan salah satu bentuk tindak pidana yang diklasifikasikan sebagai kejahatan terhadap kemerdekaan seseorang dalam KUHP. Penculikan dapat diartikan sebagai perbuatan membawa pergi seseorang tanpa hak dengan maksud agar orang tersebut (korban) dikuasai oleh penculik (pelaku). Menurut kamus hukum kontemporer yang dimaksud dengan Kidnapping adalah the crime of seizing or carrying off a person by force in order to obtain money or for political reasons, yang artinya penculikan adalah kejahatan dengan cara menculik seseorang dengan tujuan pemerasan atau politik (Basiang, 2016: 293). Penculikan yang dikenal dengan istilah mensenroof, ontvoering, kidnapping adalah perbuatan melarikan orang secara paksa dan melawan hukum dengan maksud menempatkan orang tersebut di bawah kuasanya atau kuasa orang lain. Penculikan termasuk delik berlangsung terus (voortdured delict) (Hamzah, 2008: 37).

Korban penculikan tidak terbatas pada orang dewasa saja, anak pun juga menjadi sasaran dari para pelaku penculikan. Penculikan anak-anak (kidnapping) adalah penculikan yang dilakukan terhadap orang yang belum dewasa (anak-anak) (Hamzah, 2008: 37). Yang dimaksud dengan anak sebagai korban adalah anak yang belum berumur 18 (delapan belas) tahun sebagaimana tertuang dalam Pasal 1 Angka (4) Undang-Undang Nomor 11 Tahun 2012 tentang Sistem Peradilan Pidana Anak.

Pertanggungjawaban pidana yang dalam istilah asing disebut dengan teorekenbaardheid atau criminal responsibility adalah suatu mekanisme yang menjurus kepada pemidanaan pelaku untuk menentukan apakah seseorang terdakwa atau tersangka dipertanggungjawabkan atas suatu tindakan pidana yang terjadi atau tidak (Ilyas, 2012: 73). Pertanggungjawaban berkaitan erat dengan kesalahan, oleh karenanya terdapat asas pertanggungjawaban yang menyatakan "Tiada pidana tanpa kesalahan" atau "geen straf zonder schuld" untuk menentukan apakah seorang pelaku tindak pidana dapat dimintai pertanggungjawaban dalam hukum pidana, akan dilihat apakah orang tersebut pada saat melakukan tindak pidana mempunyai kesalahan (Rusianto, 2015: 35).

Pertanggungjawaban pidana terhadap pelaku penculikan anak diatur dalam Undang-Undang Nomor 35 Tahun 2014 tentang Perubahan atas Undang-Undang Nomor 23 Tahun 2002 tentang Perlindungan Anak pada Bab XIA tentang Larangan Pasal 76F. Pelaku penculikan anak dapat dimintai pertanggungjawaban pidana apabila pelakunya telah memenuhi unsur-unsur kesalahan yakni berupa: adanya kemampuan bertanggung jawab pada diri si petindak; adanya hubungan batin antara si pembuat dengan perbuatannya, yang dapat berupa kesengajaan atau kealpaan; dan tidak adanya alsasan penghapus kesalahan atau tidak adanya alasan pemaaf (Ruba'i \& dkk., 2015: 88). Jika salah satu dari ketiga unsur tersebut tidak terpenuhi memberikan konsekuensi pada tidak dapat dinyatakan bersalah orang yang melakukan tindak pidana. Oleh karena tidak dapat dinyatakan bersalah, maka ia tidak dapat dipidana.

\section{Sanksi Pidana dan Pemidanaan terhadap Pelaku Penculikan Anak}

Hukum pidana di Indonesia mengenal adanya dua jenis sanksi yaitu sanksi tindakan (mattregel) dan sanksi pidana (straf). Sanksi tindakan merupakan sanksi yang bersifat antisipatif bukan reaktif terhadap pelaku tindak pidana yang berbasis pada filsafat determinasime dalam ragam bentuk sanksi dinamis (open system) dan spesifikasi non-penderitaan atau perampasan kemerdekaan, dengan tujuan untuk memulihkan keadaan tertentu bagi pelaku maupun korban baik perseorangan, badan hukum publik maupun perdata (Sholehuddin, 2003: 210). Sedangkan sanksi pidana adalah penderitaan atau nestapa yang sengaja dibebankan kepada orang yang melakukan perbuatan yang memenuhi unsur syarat-syarat tertentu (Andrisman, 2009: 8).

Pidana berarti hal yang dipidanakan, yaitu yang oleh instansi yang berkuasa dilimpahkan kepada seorang sebagai hal yang tidak enak dirasakan dan hal ini tidak sehari-hari dilimpahkan. Simons berpendapat bahwa pidana adalah suatu penderitaan yang oleh peraturan perundang-undangan pidana telah dikaitkan dengan pelanggaran norma, yang dengan keputusan hakim dijatuhkan pada seorang yang telah bersalah (Ruba'i \& dkk., 2015: 124).

Saleh mengklaim bahwa pidana adalah reaksi atas delik, dan ini berwujud suatu nestapa yang dengan sengaja ditimpakan Negara pada pembuat delik itu. Sedangkan Soesilo menyatakan bahwa 
pidana itu sendiri sebagai suatu perasaan tidak enak (sengsara) yang dijatuhkan oleh hakim dengan vonis kepada orang yang telah melanggar undang-undang hukum pidana (Ruba'i \& dkk., 2015: 124). Pidana mengandung unsur-unsur sebagai berikut: 1) Pengenaan atau pemberian penderitaan atau nestapa yang tidak enak dirasakan atau yang tidak menyenangkan; 2) Diberikan dengan sengaja oleh penguasa atau instansi yang berkuasa; dan 3) Dibebankan atau ditimpakan kepada seseorang yang dipersalahkan melakukan tindak pidana menurut ketentuan undang-undang (Ruba'i \& dkk., 2015: 124).

Sanksi pidana terhadap pelaku penculikan anak yang terbukti bersalah secara sah dan meyakinkan dimata hukum melakukan tindak pidana penculikan anak dapat dijatuhi hukuman sesuai yang diatur dalam Pasal 83 Undang-Undang Nomor 35 Tahun 2014 tentang Perubahan Atas UndangUndang Nomor 23 Tahun 2002 tentang Perlindungan Anak yakni berupa pidana penjara dan pidana denda.

Pemidanaan yang dalam bahasa Belanda disebut dengan straftoemeting adalah suatu proses atau cara untuk menjatuhkan hukuman/ sanksi terhadap orang yang telah melakukan tindak kejahatan (rechtsdelict) maupun pelanggaran (wetsdelict). Menurut Sudarto perkataan pemidanaan adalah sinonim dari perkataan penghukuman, beliau berpendapat bahwa: Penghukuman itu berasal dari kata dasar hukum sehingga dapat diartikan sebagai menetapkan hukum suatu peristiwa itu tidak hanya menyangkut bidang hukum pidana saja, akan tetapi juga hukum perdata, oleh karena tulisan ini berkisar pada hukum pidana, maka istilah tersebut harus disempitkan artinya, yakni penghukuman dalam arti pidana, yaitu kerap kali dengan pemidanaan atau pemberian atau penjatuhan pidana oleh hakim. Penghukuman dalam hal ini mempunyai makna yang sama dengan sentence atau veroordeling (Sudarto, 1981: 71).

Andi Hamzah menyatakan bahwa pemidanaan disebut juga sebagai penjatuhan pidana atau pemberian pidana atau penghukuman. Pemberian pidana ini menyangkut dua arti yakni: a) Dalam arti umum, menyangkut pembentuk undang-undang ialah yang menetapkan stelsel sanksi hukum pidana (pemberian pidana in abstracto); dan b) Dalam arti konkret ialah yang menyangkut berbagai badan atau jawatan yang kesemuanya mendukung dan melaksanakan stelsel sanksi hukum pidana itu (Setiadi, 2010: 21-22).

Dalam upaya penegakan hukum, terkait dengan penerapan sanksi pidana atau pemidanaan terhadap pelaku penculikan anak semuanya bergantung pada penilaian dan keyakinan hakim dengan mengacu pada Pasal 83 Undang-Undang Nomor 35 Tahun 2014 tentang Perlindungan Anak. Sesuai dengan ketentuan Pasal 1 ayat (1) Undang-Undang Nomor 48 Tahun 2009 tentang Kekuasaan Kehakiman, hakim mempunyai kewenangan untuk mengadili suatu perkara. Dalam mengambil dan memutus suatu perkara, kebebasan hakim sangat dibutuhkan untuk menjamin keobjektifan hakim. Kebebasan yang dimaksud adalah kebebasan untuk menetapkan jenis pidana, cara pelaksanaan pidana, ataupun tinggi rendahnya pidana.

Hakim dalam menjatuhkan sanksi pidana terhadap terdakwa harus benar-benar bijaksana, dibutuhkan pengetahuan yang luas dan mendalam bagi seorang hakim agar putusan yang dijatuhkan dapat mencerminkan keadilan dan terhindar dari kesewenang-wenangan. Pada akhirnya, apapun keputusan yang telah ditetapkan oleh hakim nantinya haruslah dihargai dan dihormati.

\section{SIMPULAN DAN SARAN \\ Simpulan}

Berdasarkan hasil pembahasan sebagaimana diuraikan dalam bab sebelumnya dapat disimpulkan sebagai berikut: 1) Pengaturan tentang pertanggungjawaban pidana terhadap pelaku penculikan anak diatur dalam Pasal 76F Undang-Undang Nomor 35 Tahun 2014 tentang Perubahan Atas UndangUndang Nomor 23 Tahun 2002 tentang Perlindungan Anak. Pelaku penculikan anak dapat dimintai pertanggungjawaban pidana apabila pelakunya telah memenuhi unsur-unsur kesalahan yakni berupa: adanya kemampuan bertanggung jawab pada diri si petindak; adanya hubungan batin antara si pembuat dengan perbuatannya, yang dapat berupa kesengajaan atau kealpaan; dan tidak adanya alasan penghapus kesalahan atau tidak adanya alasan pemaaf. Jika salah satu dari ketiga unsur tersebut tidak terpenuhi memberikan konsekuensi pada tidak dapat dinyatakan bersalah orang yang melakukan tindak pidana. Oleh karena tidak dapat dinyatakan bersalah, maka ia tidak dapat dipidana. 2) Sanksi pidana dan pemidanaan terhadap pelaku penculikan anak yang terbukti bersalah secara sah dan meyakinkan dimata hukum melakukan tindak pidana penculikan anak dapat dijatuhi hukuman sesuai 
yang diatur dalam Pasal 83 Undang-Undang Nomor 35 Tahun 2014 tentang Perubahan Atas UndangUndang Nomor 23 Tahun 2002 tentang Perlindungan Anak yakni berupa pidana penjara dan pidana denda. Pemidanaan terhadap pelaku penculikan anak bergantung pada peran hakim yang mengadili perkara tersebut. Hakim diberi kebebasan untuk menetapkan jenis pidana, cara pelaksanaan pidana, ataupun tinggi rendahnya pidana. Meskipun bebas namun hakim tetap mengacu pada Pasal 83 Undang-Undang Nomor 35 Tahun 2014 tentang Perlindungan Anak.

\section{Saran}

Aparat penegak hukum sebaiknya perlu teliti dan cermat dalam menentukan unsur-unsur kesalahan dari pelaku penculikan anak, hal ini perlu dilakukan untuk menghindari kesalahan dalam penerapan sanksi pidana terhadap pelaku penculikan anak. Apabila pelaku penculikan anak memang tidak memenuhi salah satu atau semua unsur dari kesalahan maka wajiblah agar orang tersebut dibebaskan/ dilepaskan dari segala tuntutan hukum. Hakim dalam menjatuhkan sanksi pidana terhadap pelaku penculikan anak kiranya mengacu pada Pasal 83 Undang-Undang Nomor 35 Tahun 2014 tentang Perlindungan Anak. Hakim juga kiranya dapat menetapkan putusan (vonis) kepada pelaku penculikan anak secara bijaksana dan adil.

\section{DAFTAR PUSTAKA}

Andrisman, T. (2009). Asas-Asas dan Dasar Aturan Hukum Pidana Indonesia. Unila.

Arsyad, M. (2017). Tinjauan Yuridis terhadap Tindak Pidana Membawa Lari Perempuan yang Belum Dewasa yang Dilakukan oleh Anak (Studi Kasus Putusan Nomor: 99/Pid.SusAnak/2015/PN.MKS) [UIN Alauddin Makassar].

Basiang, M. (2016). The Contemporary Law Dictionary (Kamus Hukum Kontemporer) (P. G. P. Utama (ed.)).

Daipon, D. (2017). Penculikan Anak (Antara Realitas dan Responsif Normatifnya menurut Pidana Islam). Humanisma: Journal of Gender Studies, 1(1), 13-23.

Daud, B. S., \& Sopoyono, E. (2019). Penerapan Sanksi Pidana terhadap Pelaku Perdagangan Manusia (Human Trafficking) di Indonesia. Jurnal Pembangunan Hukum Indonesia, 1(3), 352-365.

Fakta. (2017). Penculikan Anak. Liputan6.

Hamzah, A. (2008). Terminologi Hukum Pidana. Sinar Grafika.

Hukum, P., \& Ham, D. A. N. (2016). Kajian Yuridis tentang Perlindungan Hukum terhadap Perempuan dan Anak Korban Human Trafficking. Jurnal Panorama Hukum, 1(1), 1-16.

Ilyas, A. (2012). Asas-Asas Hukum Pidana. Rangkang Education.

Johan, B. (2008). Metode Penelitian Ilmu Hukum. Mandar Maju.

Ruba'i, M., \& Dkk. (2015). Buku Ajar Hukum Pidana. Media Nusa Creative.

Rusianto, A. (2015). Tindak Pidana dan Pertanggungjawaban Pidana Tinjauan Kritis melalui Konsistensi antara Asas, Teori, Penerapannya. PT. Fajar Interpratama Mandiri.

Setiadi, T. (2010). Pokok-pokok Hukum Penitensier Indonesia. Alfabeta.

Sholehuddin, M. (2003). Sistem Sanksi dalam Hukum Pidana Ide Dasar Double Track System dan Implementasinya. Rajawali Pers.

Sudarto. (1981). Kapita Selekta Hukum Pidana. Alumni. 